\title{
29. INTERSTITIAL WATER STUDIES, SITES 386 AND 387, LEG 43
}

\author{
Randall S. Miller, ${ }^{1}$ James R. Lawrence, ${ }^{2}$ and Joris M. Gieskes ${ }^{1}$
}

\begin{abstract}
Two sites (386 and 387) were drilled on the Bermuda Rise during Leg 43. Both show complex chemical concentration gradients in the interstitial waters. At Site 386, extremes in calcium and magnesium concentrations occur in the zone of siliceous turbidites around 350 meters. Whereas oxygen isotope changes indicate significant reactions in the lowermost sediments or underlying basalts, the changes in calcium and magnesium in the siliceous turbidites may be related to the initial step of silica diagenesis; that is, the formation of nucleation centers for opal-A recrystallization to opal-CT. The distribution of the various other chemical components of the interstitial waters is discussed.
\end{abstract}

\section{INTRODUCTION}

During Leg 43, interstitial water samples were collected at Sites 382, 384, 385, 386, and 387. Preliminary inspection of the shipboard data of Sites 382,384 , and 385 showed very small but significant changes in the calcium and magnesium concentrations with depth (see Site Reports). At Sites 386 and 387 on the Bermuda Rise, however, more complex distributions of calcium and magnesium occur. Site 6 of Leg 1 on the Bermuda Rise (Manheim and Sayles, 1969) also indicated large increases in the calcium concentration with depth. We therefore decided to concentrate our efforts on Sites 386 and 387, with particular emphasis on the former, which is characterized by extremes in the depth distribution of calcium and magnesium concentrations.

\section{METHODS}

\section{Interstitial Waters}

Methods used in this study were similar to those of Gieskes (1974) and Gieskes and Lawrence (1976). Shipboard determinations included alkalinity, salinity, chlorinity, calcium, and magnesium. These have been corrected by the method of Gieskes and Lawrence (1976) and have, in addition, been checked (magnesium) by atomic absorption methods in order to verify the minimum in magnesium concentration.

\section{Sediments}

Carbonate determinations were based on determinations of calcium on dried, powdered bulk sediments, using an acetic acid-sodium acetate leach at $p \mathrm{H} 5$. This provided a maximum value for calcite. Dolomite (not detected by X-ray) could not be determined.

$\mathrm{X}$-ray diffraction patterns of bulk sediments and carbonate-free sediments were obtained. The slides of the

\footnotetext{
${ }^{1}$ Scripps Institution of Oceanography, La Jolla, California. York.
}

latter fraction were subsequently glycolated and re-run in order to determine the percentage of expandable clay. The X-ray data are considered preliminary, and more quantitative estimates will be made in the future.

\section{Physical Properties}

Electrical resistivity and water content measurements were carried out by Mr. Russell McDuff, using procedures described by Manheim and Waterman (1974) and McDuff and Gieskes (1976).

\section{RESULTS}

Interstitial water data are presented in Tables 1 and 2, as well as in Figure 1, 2, and 3. Some of the pertinent X-ray information and carbonate contents are presented in Table 3. Data on formation factors (c.f., McDuff and Gieskes, 1976) and water contents are given in Table 4.

\section{DISCUSSION}

\section{Site 386}

Solids: The X-ray data of Table 3 confirm the lithological description given in Figure 1. The clay minerals in Units I and II are typical detrital assemblages, whereas Unit III (volcaniclastic turbidites) has clay minerals of volcanic origin, especially noticeable in the highly expandable smectites (Figure 4). Unit IV (siliceous and calcareous turbidites) shows a clay mineral assemblage in which smectite appears to dominate over illite, with the smectite being about 75 per cent expandable. A volcanic precursor of these clays seems likely, although some of the clays are possibly detrital. The cherty claystones of Unit V(a) are typically represented by opal-CT in the assemblage. Below this, smectite becomes less important and illite is the dominant clay. We speculate that much of this illite may be a diagenetic alteration product of smectite (Perry and Hower, 1970). Though the X-ray data presented above are preliminary and by no means quantitative, the interpretation obtains support from the extensive semiquantitative data of Koch and Rothe (this vol- 
TABLE 1

Interstitial Water Data, Leg 43, Site 386 and Site 387

\begin{tabular}{|c|c|c|c|c|c|c|c|c|c|c|c|c|c|}
\hline Core-Section & $\begin{array}{l}\text { Depth } \\
\text { (m) }\end{array}$ & $\mathrm{PH}^{\mathrm{a}}$ & $\underset{(\mathrm{meg} / 1)}{\mathrm{Alk}^{\mathrm{a}}}$ & $\begin{array}{c}\mathrm{S}^{\mathrm{a}} \\
(\mathrm{o} / \mathrm{oo})\end{array}$ & $\begin{array}{c}\mathrm{Cl}^{\mathrm{a}} \\
(\mathrm{o} / \mathrm{oo})\end{array}$ & $\begin{array}{c}\mathrm{Ca}^{\mathrm{a}} \\
(\mathrm{mmoles} / 1)\end{array}$ & $\begin{array}{c}\mathrm{Mg}^{\mathrm{a}} \\
(\mathrm{mmoles} / 1)\end{array}$ & $\begin{array}{c}\mathrm{Sr}^{\mathrm{a}} \\
(\mathrm{mmoles} / 1)\end{array}$ & $\underset{(\mathrm{mmoles} / 1)}{\mathrm{K}}$ & $\begin{array}{c}\mathrm{Mn} \\
(\mathrm{ppm})\end{array}$ & $\underset{(\mathrm{mmoles} / 1)}{\mathrm{SO}_{4}}$ & $\underset{(\mu \mathrm{moles} / 1)}{\mathrm{NH}_{4}}$ & $\underset{(\mu \text { moles } / 1)}{\mathrm{SiO}_{2}}$ \\
\hline \multicolumn{14}{|l|}{ Site 386} \\
\hline Surface & & & & & & & & & & & & & \\
\hline sea water & & 8.72 & 2.46 & 36.3 & 20.2 & 10.8 & 54.9 & 0.10 & 9.9 & 0.00 & 29.3 & 40 & 3 \\
\hline $1-4$ & 62.1 & 8.02 & 2.70 & 34.9 & 19.3 & 10.8 & 51.1 & 0.11 & 11.1 & 0.05 & 28.5 & 1058 & 135 \\
\hline $4-4$ & 156.8 & 7.86 & 1.19 & 35.2 & 19.4 & 32.6 & 28.4 & 0.26 & 7.5 & 7.31 & 23.4 & 1110 & 235 \\
\hline $7-2$ & 185.3 & 8.45 & 0.54 & 35.2 & 19.9 & 33.5 & 24.9 & 0.26 & 8.0 & 1.21 & 23.7 & 1533 & 104 \\
\hline $11-1$ & 261.4 & 8.48 & 0.49 & 35.2 & 20.0 & 40.1 & 18.6 & 0.44 & 7.3 & 0.50 & 23.5 & 1318 & 97 \\
\hline $14-5$ & 337.0 & 7.78 & 0.59 & 34.9 & 19.7 & 48.4 & 12.3 & 0.45 & 6.5 & 0.10 & 20.1 & 1930 & 598 \\
\hline $15-5$ & 356.4 & 7.82 & 1.14 & 34.6 & 19.7 & 46.0 & 13.5 & 0.48 & 6.1 & 0.30 & 17.4 & 1664 & 647 \\
\hline $17-5$ & 394.5 & 7.87 & 2.28 & 34.6 & 19.6 & 46.6 & 15.0 & 0.48 & 6.1 & 0.31 & 16.8 & 1677 & 700 \\
\hline $25-1$ & 480.3 & - & 1.70 & 31.1 & 18.2 & 35.1 & 21.0 & 0.41 & 4.0 & 0.79 & 10.4 & 1750 & 385 \\
\hline $29-3$ & 518.4 & - & 1.00 & 33.0 & 19.0 & 31.2 & 27.0 & 0.42 & 4.7 & 1.68 & 9.7 & 1661 & 420 \\
\hline $31-4$ & 547.0 & - & 1.10 & 33.3 & 19.5 & 36.0 & 23.6 & 0.43 & 4.3 & 1.98 & 8.8 & 1661 & 540 \\
\hline $34-5$ & 612.9 & - & - & 31.1 & 18.2 & 32.4 & 22.2 & 0.39 & 3.1 & 4.36 & 8.1 & 2000 & 485 \\
\hline $36-4$ & 650.8 & - & 2.10 & 33.0 & 19.5 & 36.4 & 28.3 & 0.40 & 2.8 & 9.50 & 7.7 & 1661 & 283 \\
\hline $40-2$ & 717.5 & - & 1.40 & 33.0 & 19.3 & 35.9 & 25.6 & 0.38 & 8.1 & 11.48 & - & 1611 & 685 \\
\hline \multicolumn{14}{|l|}{$\begin{array}{l}\text { Site } 387 \\
\text { Surface }\end{array}$} \\
\hline sea water & & $(8.80)$ & 2.44 & 36.3 & 19.9 & 10.8 & 56.3 & 0.095 & 10.7 & 0.00 & 29.2 & $(905)$ & 3 \\
\hline $1-5$ & 41.3 & 7.80 & 3.14 & 35.2 & 19.6 & 12.1 & 51.5 & 0.11 & 11.6 & 7.40 & 27.7 & 1092 & 143 \\
\hline $2-4$ & 108 & 7.80 & 4.25 & 35.2 & 19.5 & 17.3 & 47.7 & 0.145 & 9.5 & 10.8 & 23.8 & 1130 & 747 \\
\hline $3-2$ & 146 & 7.80 & 6.42 & 34.9 & 19.9 & 20.8 & 45.4 & 0.154 & 9.4 & 9.3 & 23.1 & 1150 & 759 \\
\hline $3-2$ & 175 & 7.80 & 7.84 & 35.2 & 19.4 & 23.1 & 45.1 & 0.20 & 9.25 & 8.5 & (19.6) & 1130 & - \\
\hline $16-2$ & 270 & - & 3.25 & 34.4 & 19.2 & 25.4 & 35.9 & 0.29 & 9.1 & 2.5 & - & 1450 & - \\
\hline $19-1$ & 317 & 8.10 & 3.10 & 34.1 & 20.0 & - & - & 0.35 & 7.8 & 2.0 & 15.7 & 2170 & 600 \\
\hline $23-3$ & 384 & 7.80 & 2.80 & 33.8 & 19.7 & 30.1 & 32.4 & 0.44 & 5.6 & 2.6 & 9.4 & 2007 & 378 \\
\hline $26-2$ & 422 & - & - & 33.8 & 19.6 & 29.1 & 31.1 & - & - & - & - & - & - \\
\hline $29-3$ & 478 & 7.80 & 376 & 35.2 & 20.0 & 32.3 & 34.6 & 0.52 & 5.0 & 6.9 & 14.5 & 1920 & 254 \\
\hline $32-1$ & 527 & - & - & 31.9 & 19.2 & 32.1 & 38.3 & 0.60 & 4.1 & 1.5 & 8.2 & 1720 & - \\
\hline $37-1$ & 584 & 8.20 & 2.12 & 34.1 & 20.0 & 33.3 & 30.3 & 0.57 & 5.2 & 0.9 & 8.5 & 2190 & 112 \\
\hline
\end{tabular}

${ }^{\mathrm{a}}$ Shipboard data, corrected where necessary.

TABLE 2

Oxygen Isotope Data, Site 386

\begin{tabular}{ll}
\hline $\begin{array}{c}\text { Sample } \\
(\text { Interval in cm) }\end{array}$ & $\delta \mathrm{O}^{18}(\mathrm{SMOW}) \mathrm{o} / \mathrm{oo}$ \\
\hline $4-4,144-150$ & $-0.8 \pm 0.2$ \\
$11-1,140-150$ & -0.9 \\
$17-5,140-150$ & $-2.0 \pm 0.4$ \\
$31-4,140-150$ & $-2.5 \pm 0.3$ \\
$36-4,140-150$ & $-2.6 \pm 0.2$ \\
\hline
\end{tabular}

ume). Of great interest in the latter work is the observation of appreciable quantities of dolomite in the lower parts of Unit VII (not sampled for interstitial waters). In this deeper section also, illite is the only clay mineral present. In the organic-carbon-rich black shales of the Aptian-Albian, Koch and Rothe also report the presence of siderite and rhodochrosite.

Interstitial waters. Among the most interesting results of this site are the extremes in calcium and magnesium at about 350 meters in the zone of siliceous turbidites-Unit IV(a). We shall discuss this in more detail below.

Data on dissolved sulfate and ammonia suggest that significant sulfate reduction reactions still occur at depths around 450 meters. It appears that these processes are presently not going on at significant rates at greater depths; that is, in the black shales of Unit VII.

Dissolved strontium shows a maximum at 350 meters, unit IV(a), indicating maximum production in this unit. Data on dissolved manganese are intriguing and suggest a source in the volcaniclastic turbidites of Unit
TABLE 3

Carbonate Contents and X-Ray Mineralogy, Site 386

\begin{tabular}{lrrl}
\hline Core-Section & \multicolumn{1}{c}{$\begin{array}{c}\text { Depth } \\
(\mathrm{m})\end{array}$} & \multicolumn{1}{c}{$\begin{array}{c}\mathrm{CaCO}_{3} \\
(\%)\end{array}$} & \multicolumn{1}{c}{ X-Ray } \\
\hline $1-4$ & 62.1 & 45.6 & $(1) ;(2) ;(5)$ \\
$4-4$ & 156.8 & 2.0 & $(2) ;(3) ? ;(4) ;(5)$ \\
$7-2$ & 185.3 & 4.5 & $(5) ;(6) ;(7) ;(9) ;(11)$ \\
$11-1$ & 261.4 & 8.3 & $(3) ;(4) ;(5)$ \\
$14-5$ & 337.0 & 18.5 & $(4)>(1) ;(5)$ \\
$15-5$ & 356.4 & 20.4 & $(4)>(1) ;(5)$ \\
$17-5$ & 394.5 & 27.3 & $(4)>(1) ;(2) ;(3) ;(5)$ \\
$25-1$ & 480.3 & 2.6 & $(4) ;(1) ;(2) ;(3) ;(5)$ \\
$29-3$ & 518.4 & 10.2 & $(4) ;(1) ;(2) ;(5) ;(8) ;(12)$ \\
$31-4$ & 547.0 & 13.5 & $(4) ;(1) ;(5) ;(12)$ \\
$34-5$ & 612.9 & 8.3 & $(4) ;(1) ;(5)$ \\
$36-4$ & 650.8 & 1.7 & $(4)<(1) ;(2) ;(5)$ \\
$40-2$ & 717.5 & 1.2 & $(1) ;(5) ;(8) ;(10) ? ;(13)$ \\
\hline
\end{tabular}

Note: $(1)=$ Illite, $(2)=$ Kaolinite, $(3)=$ Chlorite, $(4)=$ Smectite, (5) = Quartz, (6) = Philipsite, (7) = Clinoptilolite, (8) = Analcime, $(9)=$ Magnetite,$(10)=$ Palygorskite, $(11)$ $=$ Feldspars, $(12)=$ Opal-CT, $(13)=\mathrm{Fe} / \mathrm{Mn}$ oxides.

III and in the black clays of Unit VII. Not enough information is available on these sediments to interpret the dissolved manganese profile in detail.

The profile of dissolved potassium is of some interest. Using the data of Table 4, R. McDuff calculated a predicted diffusion profile for potassium. As can be seen in Figure 5, the data fit this predicted profile to a very good degree of precision. It appears, therefore, that the main sink for potassium is located in the black shales.

The data on the oxygen isotopes (Figure 3 ) also show a very regular decrease with depth, indicating a 

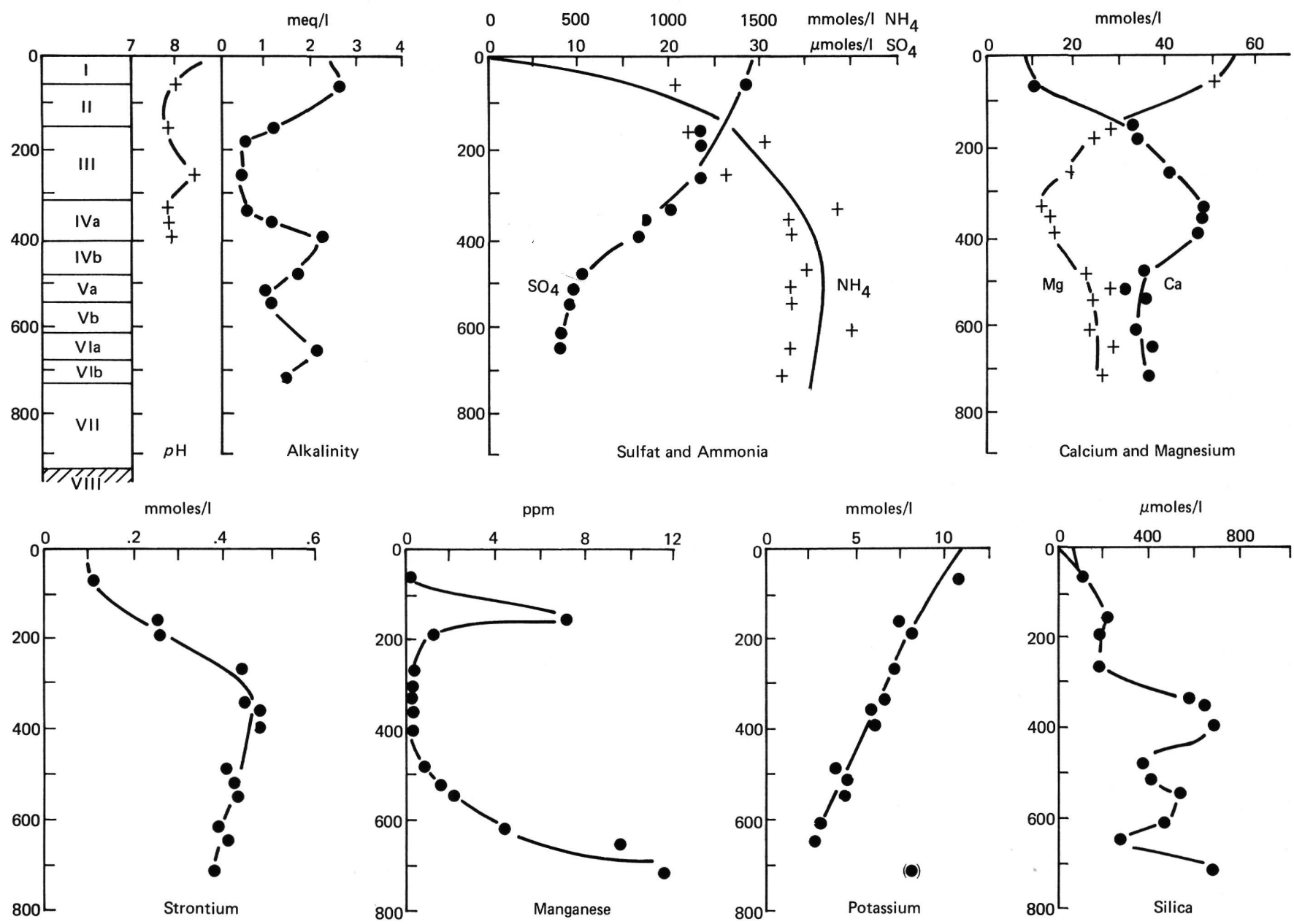

Figure 1. Interstitial water data, Site 386. Lithology: I: Marly nanno and foram ooze-lower Pleistocene; II: Zeolitic clays and nanno ooze-upper-lower Miocene; III: Volcaniclastic turbidites-Oligocene, upper Eocene; IV: (a) Siliceous turbidites-upper-middle Eocene; (b) Calcareous turbidites-middle Eocene; V: (a) Cherty claystones-middle-lower Eocene; (b) Radiolarian mudstones-lower Eocene, upper Paleocene; VI: (a) Red claystones-upper-middle Maestrichtian; (b) Banded zeolitic claystone-upper Cenomanian; VII: Greenish gray-black claystone with radiolarian sand layersupper Cenomanian, lower Albian; VIII: Basalt-altered.

TABLE 4

Diffusion Model Data

\begin{tabular}{cccc}
\hline Core-Section & $\begin{array}{c}\text { Depth } \\
(\mathrm{m})\end{array}$ & $\begin{array}{c}\text { Water } \\
\text { Content }\end{array}$ & $\begin{array}{c}\text { Formation } \\
\text { Factor }^{\mathrm{a}}\end{array}$ \\
\hline $1-4$ & 62.1 & 0.388 & 2.88 \\
$4-3$ & 153 & 0.394 & 5.40 \\
$9-3$ & 208.4 & 0.304 & 11.60 \\
$14-5$ & 337 & 0.386 & 8.00 \\
$16-4$ & 470.7 & 0.413 & 7.52 \\
$22-3$ & 446.5 & 0.237 & 16.80 \\
$27-2$ & 491.7 & 0.315 & 20.00 \\
$35-4$ & 636.2 & 0.188 & 12.80 \\
\hline
\end{tabular}

${ }^{\mathrm{a}}$ Sea water is used as a reference.

significant sink for heavy oxygen in the lower part of the sediment column or in the underlying basalts (Lawrence et al., 1975). The data do not imply very significant reactions at depths above 650 meters.

The above information, especially that on the potassium and $\delta \mathrm{O}^{18}$ profiles, emphasizes the "anomalous" nature of the calcium and magnesium concentration gradients. It appears that an additional reaction has superimposed calcium and magnesium changes upon the usually expected calcium and magnesium gradients, which often coincide with $\delta \mathrm{O}^{18}$ gradients (Lawrence et al., 1975; Gieskes et al., 1978. A similar observation was made during Leg 35 at Site 323 (Gieskes and Lawrence, 1976; Kastner and Gieskes, 1976), where alteration reactions of volcanic matter and silicification reactions were the cause of the uptake of magnesium and potassium and the release of calcium. At Site 386, potassium does not appear to be involved, and the change in the concentration of calcium at the maximum is about equivalent to the change in magnesium, with little or no change in alkalinity. The concentration profiles can best be understood in terms of reactions occurring in the siliceous turbidites at such rates that these extremes are superimposed on the "normal" diffusion gradients. Perhaps the reaction rates have increased with burial depth and temperature, thus leading to the observed extremes in the concentration profiles. Of course, the concentrations above 350 meters 

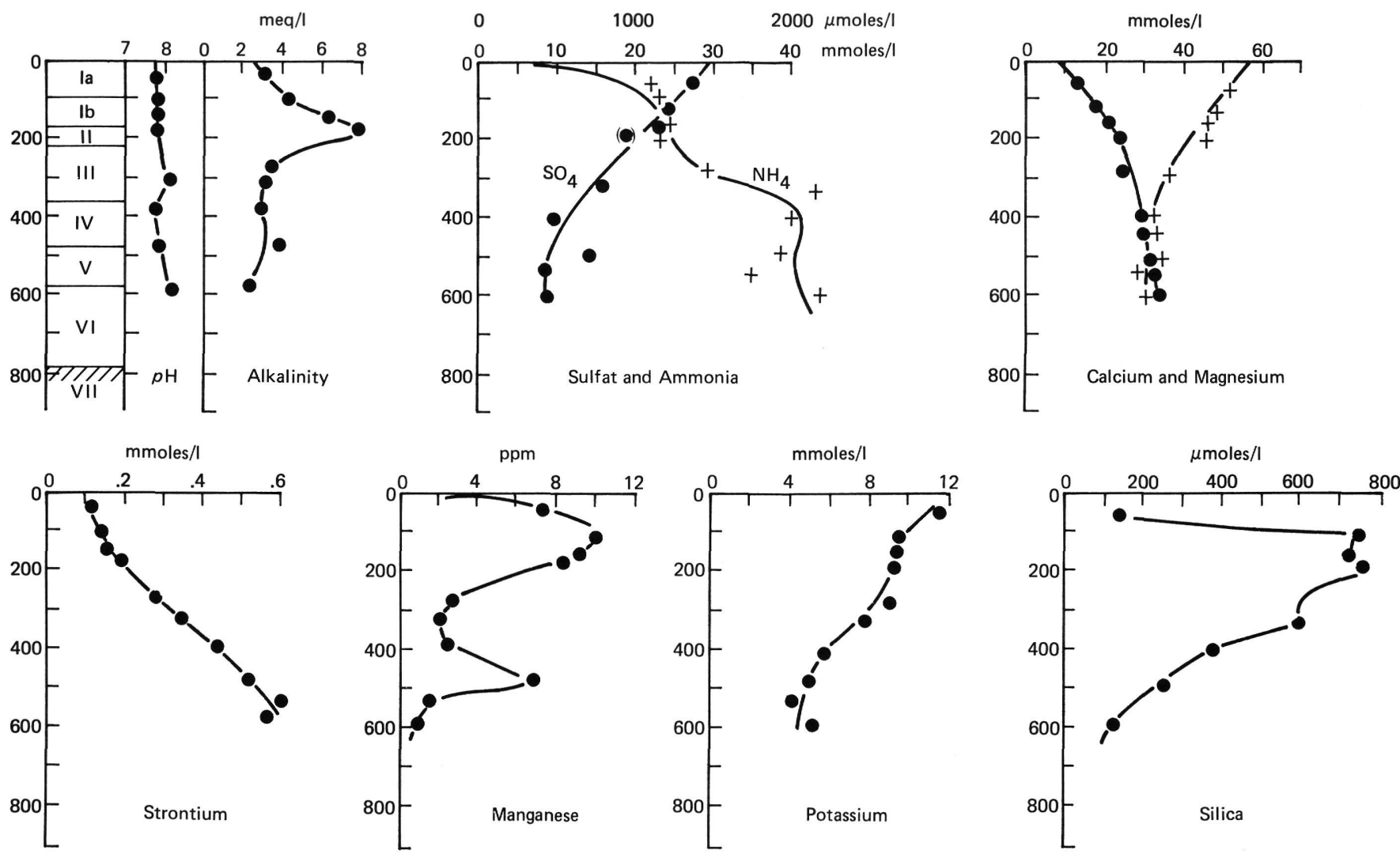

Figure 2. Interstitial water data, Site 387. Lithology: I: (a) Pelagic clay-Pleistocene (?)-upper Oligocene; (b) Radiolarian mud-upper Oligocene to middle Eocene; II: Siliceous turbidites-lower-middle Eocene; III: Silicified claystone, radiolarian mudstone, and chert--lower-middle Eocene; IV: Silicified claystones; chalks; red claystones-Danian-Campanian; V: Greenish gray-black claystone-Aptian-Cenomanian; VI: Limestone-Barremian to Berriasian; VII: Basalt.

also suggest some reaction in the higher horizons. Perhaps precipitation reactions of a magnesium phase (hydroxide?) occur in the siliceous turbidites, with alkalinity being provided by calcite dissolution. Such a magnesium compound has been suggested by Kastner et al. (1976) as the nucleation center for opal-CT in siliceous oozes. It is of great importance to identify the nature of this magnesium phase, and we intend, accordingly, to make a very intensive study of the siliceous turbidites. In addition to the experimental work of Kastner et al. (1977), uptake of magnesium in siliceous oozes was also noticed by Donnelly and Merrill (1977).

The increase in the strontium concentration at 350 meters is too high to be explained by simple calcite dissolution (Sayles and Manheim, 1975; Gieskes, 1976), as the $\Delta \mathrm{Sr} / \Delta \mathrm{Ca}$ ratio is about $100 \times 10^{-4}$ (atomic) whereas carbonates generally yield $\mathrm{Sr} / \mathrm{Ca}$ ratios of 20 $\times 10^{-4}$ (atomic). This would also imply very intensive recrystallization of calcite in these horizons.

\section{Site 387}

No solids studies were made by us, but the data of Koch and Rothe (this volume) suggest lithologies and mineralogies very similar to those of Site 386 . Hole 387 , however, is characterized by much slower accumulation rates.

Sulfate reduction is again of importance in the deeper, organic-carbon-rich sediments. Strontium ap- pears to have its main source in the lowermost chalks and limestones.

No extreme was observed in calcium or magnesium, although the concentration profiles suggest reactions above a depth of 200 meters. Perhaps at these lower accumulation rates diffusional processes become as important in rate as the reactions, thus preventing the build-up of extremes in the concentration-depth profiles.

If studies on the siliceous turbidites of Site 386 are successful, we intend to extend these investigations to the same lithology of Site 387.

\section{ACKNOWLEDGMENTS}

We wish to acknowledge the help of Dr. Miriam Kastner. Russell E. McDuff made the resistivity measurements and diffusion model calculations. Richard Meyers carried out the shipboard chemical work, and his careful analyses are fully appreciated. Guntwin Galleisky and Wayne Akiyama were helpful with some of the shore laboratory chemical analyses. This work was generously supported by NSF Grants DES 72-01410 (J.M.G.) and OCE 75-02968 (J.R.L.).

\section{REFERENCES}

Donnelly, T. W. and Merrill, L., 1977. The scavenging of magnesium and other chemical species by biogenic opal in deep sea sediments: Chem. Geol., v. 19, p. 167-186. 


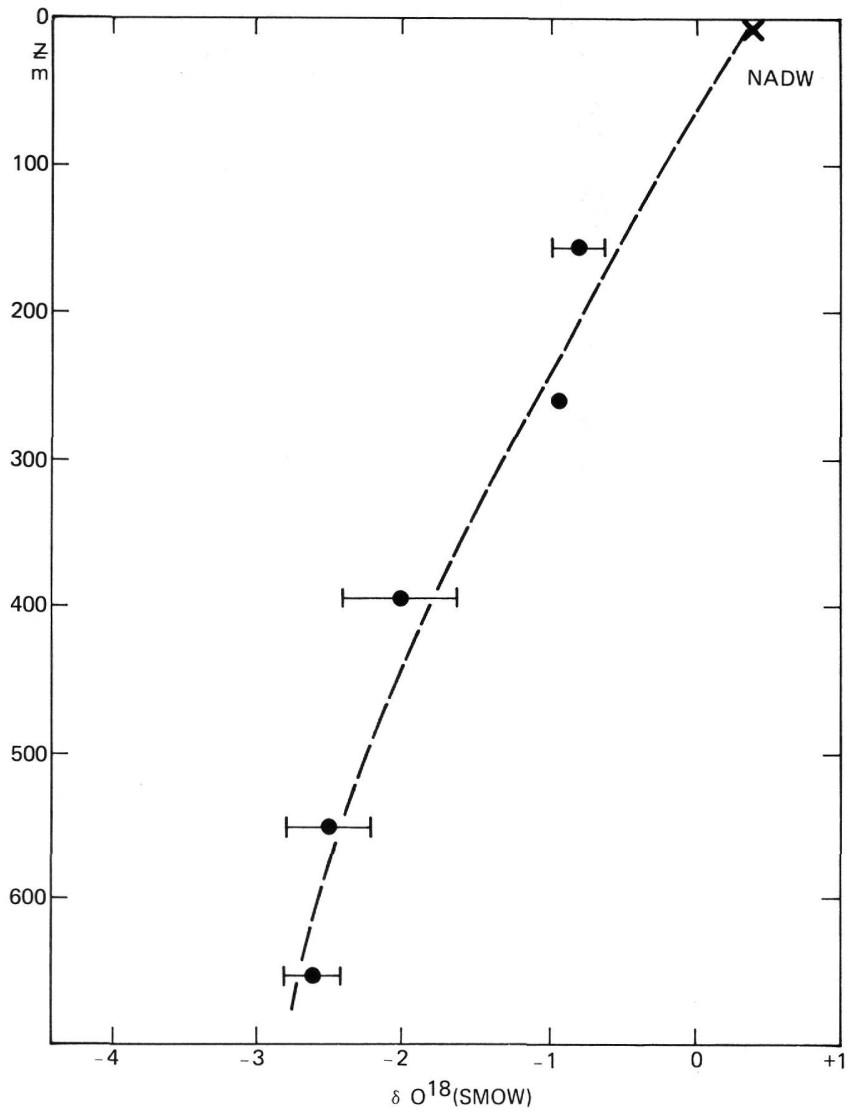

Figure 3. Oxygen isotope composition of interstitial waters, Site 386.

Gieskes, J. M., 1974. Interstitial water studies, Leg 25. In Simpson, E. S. W., Schlich, K. et al., Initial Reports of the Deep Sea Drilling Project, v. 25: Washington (U. S. Government Printing Office), p. 361-394.

, 1976. Interstitial water studies, Leg 33. In Schlanger, S. O., Jackson, E. D., et al., Initial Reports of the Deep Sea Drilling Project, v. 33: Washington (U. S. Government Printing Office), p. 563-570.

Gieskes, J. M. and Lawrence, J. R., 1976. Interstitial water studies Leg 35. In Hollister, C. D., Craddock, C., et al., Initial Reports of the Deep Sea Drilling Project, v. 35: Washington (U. S. Government Printing Office), p. 407-424.

Gieskes, J. M., Lawrence, J. R., and Galleisky, G., 1976. Interstitial water studies Leg 38. In Talwani, M., Udintsev, et al., Initial Reports of the Deep Sea Drilling Project, Supplement to Volumes 38, 39, 40 and 41: Washington (U. S. Government Printing Office), p. 121-134.

Kastner, M. and Gieskes, J. M., 1976. Interstitial water profiles and sites of diagenetic reactions, Leg 35, DSDP, Bellingshausen Abyssal Plain. Earth Planet. Sci. Lett., v. 33, p. 11-20.

Kastner, M., Keene, J., and Gieskes, J. M., 1977. Diagenesis of siliceous oozes. I. Chemical controls on the rate of opalA diagenesis, an experimental study: Geochim. Cosmochim. Acta., v. 41, p. 1041-1059.

Lawrence, J. R., Gieskes, J. M., and Broecker, W. S., 1975. Oxygen isotope and cation composition of DSDP pore waters and the alteration of Layer II basalts: Earth Planet. Sci. Lett., v. 27, p. 1-10.

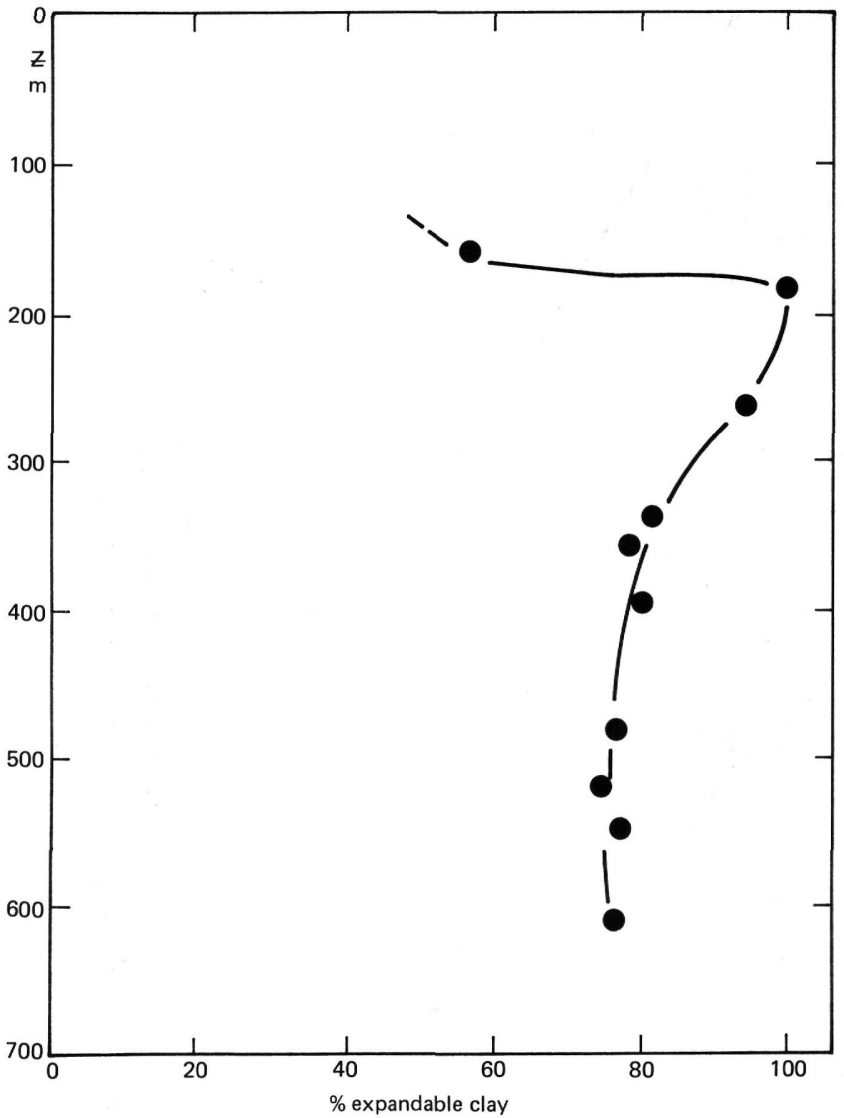

Figure 4. Percent expandable clay, Site 386.

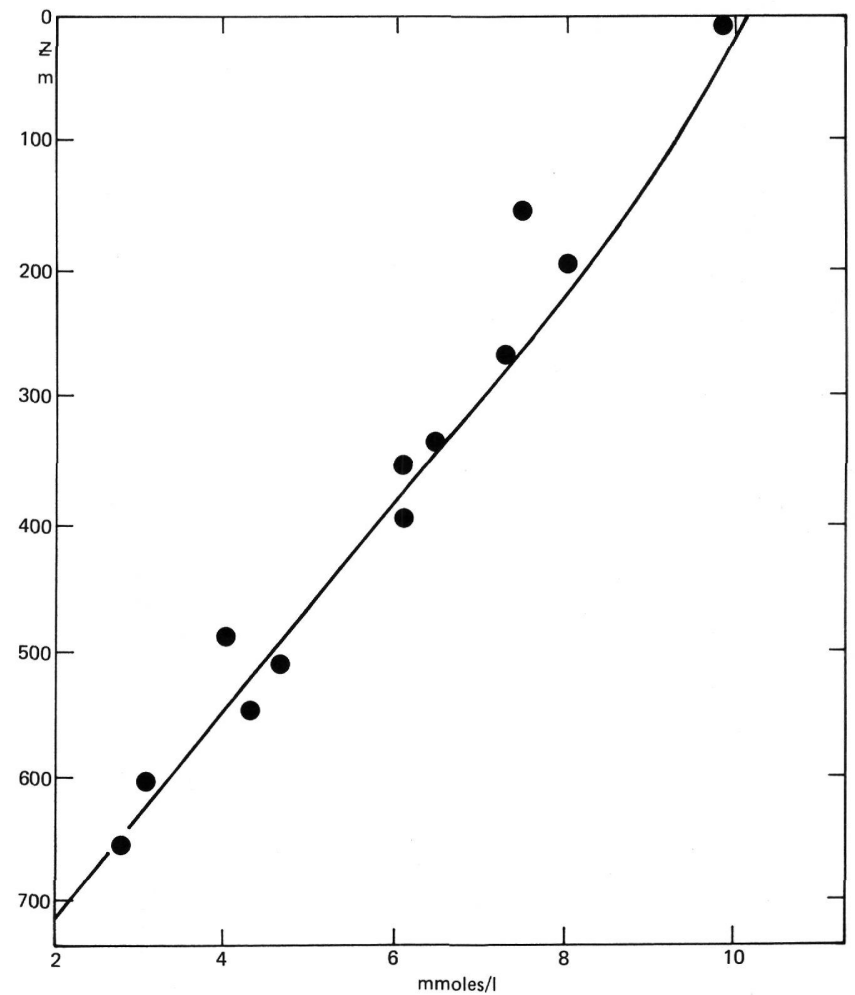

Figure 5. Diffusion model data for dissolved potassium, Site 386. 
Manheim, F. T. and Sayles, F. L., 1969. Interstitial water studies on small core samples, Deep Sea Drilling Project, Leg 1. In Ewing, M. et al., Initial Reports of the Deep Sea Drilling Project, v. 1: Washington (U. S. Government Printing Office), p. 403-410.

Manheim, F. L. and Waterman, L. S., 1974. Diffusimetry (diffusion constant estimation) on sediment cores by resistivity probe In von der Borch, C. C., et al., Initial Reports of the Deep Sea Drilling Project, v. 22: Washington (U. S. Government Printing Office), p. 663-670.
McDuff, R. E. and Gieskes, J. M., 1976. Calcium and magnesium profiles in DSDP interstitial waters: Diffusion or reaction?: Earth Planet. Sci. Lett., v. 33, p. 1-10.

Perry, E. A. and Hower, J., 1970. Burial diagenesis in Gulf Coast pelitic sediments: Clays and Clay Minerals, v. 18, p. 165-177.

Sayles, F. L. and Manheim, F. T., 1975. Interstitial solutions and diagenesis in deeply buried marine sediments: Results from the Deep Sea Drilling Project: Geochim. Cosmochim. Acta, v. 39, p. 103-127. 